\title{
Performance of the Clean Development Mechanism(CDM) Projects of the Asean Countries
}

\section{아세안 국가들의 청정개발체제 사업에 대한 성과 분석}

\author{
Michael A. Gragasin* ${ }^{*}$ Soon Chul Ko** \\ 마이클 그라가신·고순철
}

\section{Abstract}

청정개발체제 (CDM) 는 1997년 교토의정서(Kyoto protocol)를 통해 확립된 온 실가스 배출과 관련된 선진국과 개도국 간 협력 기제의 하나이다. 청정개발체제 는 기본적으로 선진국의 정부 또는 민간조직이 개도국에서 배출감축 프로젝트를 수행하고, CER (Certified Emission Reduction)의 형태로 배출권을 얻는 것을 허 용하고, $\mathrm{CER}$ 을 자국의 배출감축목표 달성을 위해 사용할 수 있도록 하고 있다.

이 연구의 목적은 아세안 국가들의 청정개발 메커니즘의 성취도를 알아보는 데 있으며, 자료는 2010년 10월 15일 현재 유엔기후변화기본협약(UNFCCC)에 등록된 254개 청정개발체제 사업을 대상으로 분석하였다.

이 연구의 결과, 전체 254 개 사업 중 $20 \%$ 만이 탄소배출권을 받은 것으로 나 타났으며, 실제 탄소배출권의 총량은 650 만 톤이지만, 이는 전체 사업계획서에 반영된 양의 $15 \%$ 에 불과한 것으로 분석되었다. 또한 아세안 국가의 $\mathrm{CDM}$ 사업 과 관련된 장애 요인으로서는 (1)사업 등록과 탄소배출권 승인 간 시간 격차가 존재하고, (2) 사업계획과 실제 승인량에 차이가 나타나며, (3) 특히 소규모 사

* Philippine Center for Postharvest Development and Mechanization, Department of Agriculture(DA-PhilMech), Philippines. e-mail: kitgragasin@yahoo.com

** Dep't of Regional Development, Hyupsung University, South Korea. Corresponding author.e-mai:kosc@uhs.ac.kr 
업의 경우 높은 거래 비용 때문에 등록 후 배출승인을 신청하지 않고 있는 것으 로 나타나고 있다. 이러한 연구결과는 아세안국가들이 CDM사업을 수행하는 데 있어서 선진국들의 주요 파트너가 되고 있지만, 실제로 사업을 통한 탄소배출량 은 제한적일 수 있음을 의미한다. 따라서 일부 아세안 국가에서 교토의정서에 따라 자체적으로 탄소배출감축을 시도하고 있음을 고려할 때, 자체적인 $\mathrm{CDM}$ 의 성공적인 경영, 수행, 운영을 위해 더 많은 선진국들의 협력과 지원이 주어질 필요가 있다.

주요어(key words): 청정개발체제(CDM), 탄소배출감축(CER)

\section{Introduction}

The urgency to reduce carbon emission is imperative among nations not only for developed countries but also for developing countries (Olmstead \& Stavins, 2010). During the $15^{\text {th }}$ Conference of Parties to the United Nations Framework Convention on Climate Change(UNFCCC) that was held in Copenhagen, Denmark in December 2009, the world has witnessed a dynamic period of international debate on the post-Kyoto with the end goal of hammering out a meaningful, fair, binding international environmental agreement. On the final day, a dramatic last-gasp deal was hammered out-the Copenhagen Accord.

The Accord recognized the need to limit global temperatures from rising to no more than $2^{\circ} \mathrm{C}\left(3.6^{\circ} \mathrm{F}\right)$ above pre-industrial level. Countries were asked to spell out on 31st January 2010 
their pledges for curbing carbon emissions by 2020 though the deal did not spell out penalties for any country that fail to meet its promise.

The members of the Association of Southeast Asian Nations (ASEAN) during the $17^{\text {th }}$ ASEAN Summit in Hanoi, Vietnam on April 9, 2010 have affirmed their commitments to the UNFCCC. As a start, some members of the ASEAN countries, i.e., Malaysia, Singapore and Indonesia as developing nations that have no binding commitments under Kyoto Protocol, have committed under the Copenhagen Accord to reduce carbon emissions by $40 \%, 7-11 \%$, 26\% by 2020, respectively, including the Philippines which aims to reduce its carbon emissions by 5\% from its 1990 level.

With the near closing of the Kyoto protocol timeframe by 2012, this research aimed to: (i) investigate the performance of the ASEAN nations as one active partners of developed countries in achieving the goal of Kyoto Protocol; (ii) determine whether the potential benefits of joining the CDM have been achieved; and, (iii) identify barriers that impinge the implementation and development of the CDM program. 


\section{Theoretical Background}

\subsection{Background and major debates on the CDM}

Uncertainty concerning a future international climate agreement including the prospects for CDM in the post-2012 period continues (World Bank, 2010b). Unlike the Copenhagen Accord, the Kyoto Protocol set legally binding Greenhouse Gas(GHG) emission reduction targets for developed countries and countries in transition. The Kyoto Protocol defines three mechanisms to achieve these emission reduction targets in a cost-effective way, such as: (i) international emissions trading(IET); (ii) joint implementation(JI), and (iii) clean development mechanism(CDM). The UNFCCC negotiation process has shown commitment of using markets to enhance the cost-effectiveness of global mitigation actions, and reforms designed to strengthen the CDM.

The CDM is one of the flexible instruments aimed at helping industrialized countries reach their emission reduction commitments in a cost-efficient manner by purchasing credits from emission reduction projects in developing countries. At the same time, the CDM provides benefits to host-developing countries by promoting investment in sustainable development and facilitating technology transfer. Given the new nature of the CDM, however, procedures and guidelines have been developed to safeguard and check the authenticity of carbon credits in the market.

Through the years, there are lots of concerns regarding the 
implementation of CDM (Capoor \& Ambrosi, 2008). Some reports have pointed out that the structure and procedures of the CDM are complex and costly, particularly the high transaction costs that emerge in the CDM activities (Lloyd \& Subbarao, 2008). Reports likewise pointed out that project developers experience continuous frustration regarding the regulatory process. Inefficiencies along the project cycle cause delays and losses of Certified Emission Reduction (CER) volumes (Lutken \& Michaelowa, 2008).

\subsection{State of CDM Projects in the ASEAN Region}

Cognizant of the mounting global concern over the environment and the ASEAN's obligations to its people in fulfilling the objective of environmental sustainability in the context of sustainable development, the ASEAN have pledged to complement and support the efforts of global and regional organizations to tackle environmental issues.

In line with this, countries in the ASEAN Region become active partners of the developed countries in the implementation of CDM projects. Though still considered small compared to the total number of projects of China, India and Brazil(BIC countries), four out of the top ten countries in the world with the most number of CMD projects came from the ASEAN Region as of October 15, 2010 (Table 1). These include Malaysia, Indonesia, Philippines and Thailand. The total number of projects 
of the ASEAN Region represents $10.5 \%$ of the total number of CDM projects registered at the UNFCCC.

〈Table 1〉 Registered CDM project activities by host country, as of October 15, 2010

\begin{tabular}{c|c|c|c|c|c}
\hline Country & $\begin{array}{c}\text { No. of registered } \\
\text { Projects }\end{array}$ & Percent & Country & $\begin{array}{c}\text { No. of registered } \\
\text { Projects }\end{array}$ & Percent \\
\hline China & 986 & 40.6 & South Korea & 46 & 1.9 \\
\hline India & 538 & 22.2 & Philippines & 41 & 1.7 \\
\hline Brazil & 179 & 7.4 & Thailand & 39 & 1.6 \\
\hline Mexico & 123 & 5.2 & Chile & 38 & 1.6 \\
\hline Malaysia & 85 & 3.5 & Others & 305 & 12.6 \\
\hline Indonesia & 48 & 2.0 & Total & 2,428 & 100.0 \\
\hline
\end{tabular}

Based on the record of UNFCCC, the biogas sector attracted the largest number of CDM projects. Biomass, methane avoidance, methane recovery and utilization, and hydro power were also the predominant sector or type of projects.

As of October 15, 2010, the ASEAN countries have already registered a total of $254 \mathrm{CDM}$ projects to the UNFCCC wherein 20 of which have already received CER credits. As shown in Table 2, the cumulative CER credit has already reached 6.5 million $\mathrm{tCO}_{2} \mathrm{e}$ with Vietnam topping the list with 4.5million $\mathrm{tCO}_{2} \mathrm{e} \mathrm{CER}$ credit. This was attributed to the registration of the Randong Oil Field Associated Gas Recovery and Utilization Project in 2006 with an expected CER credit of 1.1 million per year. It can be deduced that without this project of Vietnam, 
the performance of CER delivery of the ASEAN countries would be very low. As such, while Malaysia and Indonesia have the most number of CDM projects among the ASEAN countries, Vietnam top the list in terms of total CER credits earned that accounts for $69 \%$ of the total CER credits earned.

〈Table 2〉 Estimated and actual CER of registered CDM projects of host ASEAN countries as of October 15, 2010

\begin{tabular}{c|c|c|c|c}
\hline \multirow{2}{*}{} & \multicolumn{2}{|c|}{ Registered CDM Projects } & \multicolumn{2}{c}{ Actual CERs Issued } \\
\cline { 2 - 5 } & $\begin{array}{c}\text { No. of } \\
\text { Projects }\end{array}$ & $\begin{array}{c}\text { Estimated Potential } \\
\text { CERs/year } \\
\left(\mathrm{tCO}_{2} \mathrm{e}\right)\end{array}$ & $\begin{array}{c}\text { No. of Projects } \\
\text { with Issued } \\
\text { CER }\end{array}$ & $\begin{array}{c}\text { Total CER Issued } \\
\text { since Registration } \\
\text { tCO }_{2} \text { e }\end{array}$ \\
\hline Cambodia & 4 & 124,356 & 0 & 0 \\
\hline Indonesia & 48 & $4,326,425$ & 6 & 394,863 \\
\hline Laos & 1 & 3,338 & 1 & 2,168 \\
\hline Malaysia & 86 & $5,203,091$ & 6 & 723,916 \\
\hline Philippines & 41 & $1,474,159$ & 3 & 95,428 \\
\hline Singapore & 1 & 15,205 & 0 & 0 \\
\hline Thailand & 39 & $2,181,137$ & 2 & 815,224 \\
\hline Vietnam & 34 & $2,153,495$ & 2 & $4,487,743$ \\
\hline ASEAN & 254 & $15,481,209$ & 20 & $6,519,342$ \\
\hline
\end{tabular}

Based on the individual project design document of these 254 projects, the annual CER credits were estimated at 15.4 million $\mathrm{tCO}_{2} \mathrm{e}$, which was $4 \%$ of the world's total. Likewise, despite the consistent registration of CDM projects per year by the ASEAN countries at UNFCCC as shown in Figure 1, it is noteworthy to mention that the 20 projects with earned 
CER credits was only $8 \%$ of the world's total. As of October 15, 2010, the total number of registered CDM projects at UNFCCC has already reached 2,428.

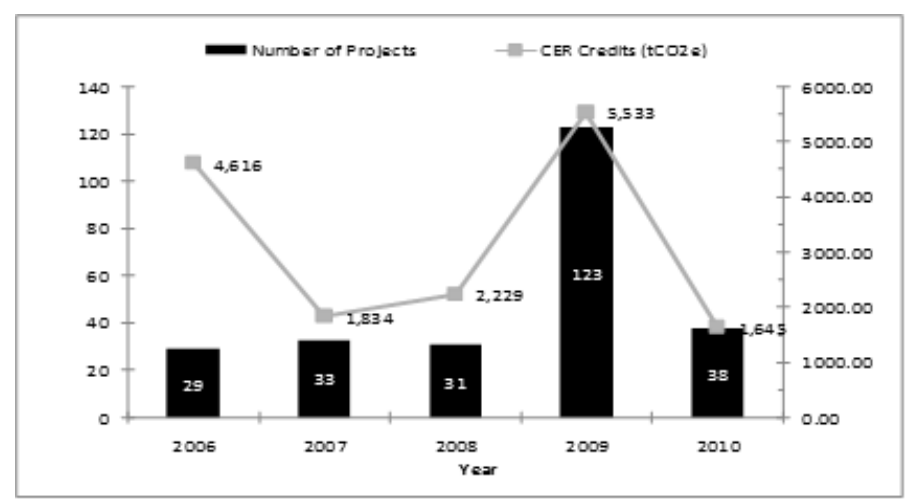

〈Figure 1〉 Total number of registered CDM projects with their expected CER credits per year in the ASEAN Region, as of October 15, 2010

\section{Research Method}

\subsection{Data gathering}

The data used in the analysis were taken from the databases compiled by the CDM Secretariat of the UNFCCC as well as the database of the Institute for Global Environmental Strategies (IGES) which are both accessible at their respective websites. 
The total number of study samples has reached 254. This figure represents the total number of registered CDM projects of the ASEAN countries at UNFCCC as of October 15, 2010, the cut-off date of the study. All documents pertaining to the project, such as project design document (PDD); letters of approval of the host country and the foreign partner implementing party; and, the validation, registration, monitoring and verification reports, were all downloaded at the website of UNFCCC for analysis.

\subsection{General Features of Data}

The total number of samples per host country and per category is shown in Table 3. Malaysia has the most number of study samples being the country with most number of CDM registered projects while Singapore and Laos have the least with one project each. Of the total 254 data sets, $71 \%$ of which was categorized by UNFCCC as small scale CDM project activity (SSC). UNFCCC has defined small scale CDM project activity as those renewable project activities with a maximum output capacity of up to 15 megawatts (or an appropriate equivalent); energy efficiency improvement project activities which reduce energy consumption, on the supply and/or demand side, by up to the equivalent of 15 gigawatts-hours (GWh) per year; and, other project activities that both reduce anthropogenic emissions by sources and directly emit 
less than 15 kilotonnes of carbon dioxide equivalent annually.

〈Table 3〉 Registered projects of ASEAN countries at UNFCCC as of October 15, 2010, By Country, By Classification of Project*

\begin{tabular}{c|r|r|r}
\hline Country & Large & Small & Total \\
\hline Cambodia & 0 & 4 & 4 \\
\hline Indonesia & 18 & 30 & 48 \\
\hline Laos & 0 & 1 & 1 \\
\hline Malaysia & 18 & 68 & 86 \\
\hline Philippines & 9 & 32 & 41 \\
\hline Singapore & 0 & 1 & 1 \\
\hline Thailand & 19 & 20 & 39 \\
\hline Vietnam & 9 & 25 & 254 \\
\hline Total & 73 & 181 & 100.0 \\
\hline Percent to & 28.7 & 71.3 & \\
Total & & & 34 \\
\hline
\end{tabular}

* as classified by UNFCCC

Table 4 shows the total number of CDM registered projects being implemented by the host countries with the developed countries. It is evident that the United Kingdom was the most active partner of the ASEAN countries in implementing CDM projects followed by Japan, Netherlands, Switzerland, Denmark, Germany and others. It is evident that there were at least 16 CDM projects that solely implemented by the ASEAN countries, not being collaborated with developed countries. 
〈Table 4〉 No. of CDM registered projects with developed countries as of October 15, 2010

\begin{tabular}{c|r|r|r|r|r|r|r|r|r}
\hline Country & UK & Japan & $\begin{array}{c}\text { Netherl } \\
\text { ands }\end{array}$ & $\begin{array}{c}\text { Switzer } \\
\text { land }\end{array}$ & Denmark & Germany & Others & None & Total \\
\hline Cambodia & 0 & 1 & 0 & 0 & 0 & 0 & 0 & 3 & 4 \\
\hline Indonesia & 5 & 16 & 14 & 8 & 0 & 2 & 1 & 2 & 48 \\
\hline Laos & 0 & 1 & 0 & 0 & 0 & 0 & 0 & 0 & 1 \\
\hline Malaysia & 26 & 13 & 14 & 4 & 14 & 10 & 5 & 0 & 86 \\
\hline Philippines & 31 & 5 & 1 & 0 & 0 & 0 & 3 & 1 & 41 \\
\hline Singapore & 0 & 1 & 0 & 0 & 0 & 0 & 0 & 0 & 1 \\
\hline Thailand & 9 & 14 & 0 & 2 & 5 & 1 & 1 & 7 & 39 \\
\hline Vietnam & 6 & 6 & 6 & 6 & 0 & 3 & 4 & 3 & 34 \\
\hline Total & 77 & 57 & 35 & 20 & 19 & 16 & 14 & 16 & 254 \\
\hline
\end{tabular}

In this paper, we followed the classification used by the Institute for Global Environmental Strategies (IGES) in grouping the CDM projects, as follows: (i) Afforestation and Reforestation; (ii) Biogas; (iii) Biomass; (iv) Cement; (v) Energy Efficiency; (vi) Fuel Switch; (vii) Hydro Power; (viii) Methane Avoidance; (ix) Methane Recovery and Utilization; (x) $\mathrm{N}_{2} \mathrm{O}$ Decomposition; (xi) Other Renewable Energies; (xii) PFC Reduction; (xiii) Waste Gas/Heat Utilization; and (xiv) Wind Power. Table 5 shows the composition of the study sample per type of project. As manifested in the table, biogas and biomass composed more than half of the total study sample with 114 and 42 projects, respectively. 
〈Table 5〉 Registered CDM Projects of ASEAN as of October 15, 2010, Per Type of Project

\begin{tabular}{c|c|c}
\hline Project Type & No. of Projects & Percent to Total \\
\hline Afforestation and Reforestation & 1 & 0.4 \\
\hline Biogas & 114 & 44.9 \\
\hline Biomass & 42 & 16.5 \\
\hline Cement & 3 & 1.2 \\
\hline Energy Efficiency & 7 & 2.8 \\
\hline Fuel Switch & 2 & 0.8 \\
\hline Hydro Power & 22 & 8.7 \\
\hline Methane Avoidance & 26 & 10.2 \\
\hline Methane Recovery and Utilization & 20 & 7.9 \\
\hline N 2 D Decomposition & 3 & 1.2 \\
\hline Other Renewable Energies & 4 & 1.6 \\
\hline PFC Reduction & 1 & 0.4 \\
\hline Waste Gas/Heat Utilization & 7 & 2.8 \\
\hline Wind Power & 2 & 0.8 \\
\hline Total & 254 & 100.0 \\
\hline
\end{tabular}

\subsection{Data Analysis}

The 254 data sets have been processed and analyzed using Microsoft Excel 2010. In particular, the Shazam (Version 10), a comprehensive econometrics and statistics package software, has been used for the Probit regression analysis. The frequency distribution and the Probit regression analyses were undertaken in order to test the objectives of this study. 


\section{Findings}

\subsection{Barriers to CDM Implementation}

Due to the characteristics of international and domestic procedures, there were inherent vulnerabilities during the implementation of CDM projects by the host ASEAN countries. This includes the following:

\subsubsection{Bottleneck dur ing $r$ egistration and CER issuance}

The largest risks associated during the implementation of CDM projects were twofold: (i) rejection and (ii) delay. Per record of UNFCCC, several projects of the ASEAN countries for registration have been rejected by UNFCCC-EB for some technical reasons.

To appreciate the issue regarding the bottlenecks during registration and CER issuance, it is important to note the procedures by which a project proposal becomes a CDM project (implementation phase) until the time that it started to generate CERs (operational phase). It should be reiterated that the objective of the implementation phase is to have the project registered at the UNFCCC and as the project has been registered and starts running, the operational phase begins with the objective of having the CERs issued.

In the implementation phase, the project design document (PDD) is developed. Based on this document, the host country 
is tasked to issue a Letter of Approval (LoA). The independent validation of the PDD is done by the Designated Operational Entity (DOE). After the successful validation and the issuance of the LoA, the CDM project applied for registration at the UNFCCC through the CDM Executive Board (CDM-EB).

During operational phase, the project shall start with the participants' submission of the monitoring report to DOE for verification. The DOE will check if the monitoring plan has been fully carried out in accordance with the PDD and the reported emission reduction has been delivered. If these two aspects are satisfactory fullfilled, the DOE shall then certify the emission reductions by issuing a certification report that assures the CDM project activity achieved the verified amount of emission reductions within the reported period. The DOE then will request the CDM-EB to issue the verified amount of CER.

For the purpose of this analysis, the lead time has been estimated during project implementation (from the first day of public hearing to the actual date of registration), and during project operation, (from project registration to the issuance of the first CER credit) for all projects that already earned CER credits. The result of our estimation showed that on the average, the CDM projects of the ASEAN countries have taken around 426 days and 1,355 days to complete the requirements during project implementation and project operation, respectively, or a total of 1,781 days (4.9 yrs) before the project has started 
to receive CER credits. As highlighted from this result and as illustrated in Table 6 , it can be deduced that the bulk of work associated in the implementation and operation of CDM projects actually took place after registration.

It should be emphasized that based on the schedule of CER issuance of these 20 projects as manifested in their individual project design document, the total potential CER credits was projected at 43 million $\mathrm{tCO}_{2} \mathrm{e}$. As such, the actual 6.5 million $\mathrm{tCO}_{2} \mathrm{e}$ CER credits earned was only $15 \%$ of the total potential CER credits that could be earned from these projects.

〈Table 6〉 Average lead time of CDM projects during implementation and operational phases per country

\begin{tabular}{c|c|c} 
& From Public Hearings to Registration & From Registration to First CER Issuance \\
\hline Cambodia & 420 & - \\
\hline Indonesia & 393 & 1,287 \\
\hline Laos & 338 & 1,267 \\
\hline Malaysia & 443 & 1,607 \\
\hline Philippines & 517 & 1,247 \\
\hline Singapore & 399 & - \\
\hline Thailand & 458 & 1,216 \\
\hline Vietnam & 440 & 1,504 \\
\hline
\end{tabular}

The above findings suggest that while the ASEAN nations became active partners of the developed countries in implementing CDM projects, the end result of having these projects earned CER credit were very limited. 
It is essential to take into account the impact of delays during project implementation and operation. It is supposed that the overall delays pushed back the date on which the projects have started generating CERs that in effect, reduced the potential volume of CERs being transacted in a given period. These delays can therefore be particularly costly on the part of participating countries.

\subsubsection{Low performance of projects}

In addition to the problems concerning delay in project implementation and operation, another problem was the low rate of actual CER credit received. Actual CERs verified and issued by the CDM-EB did not always agree with what has been written in the project design document. For the 20 registered projects that already received CER credits, the average performance rate was only $66 \%$, based on the comparison of the actual CER issued and approved by UNFCCC and the annual estimated CER credit written in the project design documents.

Interestingly, as shown in Table 7, the project type and category have some important influence on the performance rate. While Cement and Waste Gas Heat Utilization projects have a modest performance rate of $67.8 \%$, the Biogas projects have achieved a performance rate of only $35.8 \%$. 
$\langle$ Table 7〉 Performance rate of CER issuance of ASEAN countries per project type

\begin{tabular}{c|c|c}
\hline & No. of Projects & Performance Rate(\%) \\
\hline Waste Gas/Heat Utilization & 3 & 67.8 \\
\hline Energy Efficiency and Renewable Energy Projects & 6 & 52.9 \\
\hline Methane Recovery and Utilization & 1 & 45.0 \\
\hline Cement & 2 & 67.3 \\
\hline Biomass & 6 & 58.1 \\
\hline Biomgas & 2 & 35.8 \\
\hline
\end{tabular}

\subsubsection{Limited number of actual projects applied for CER credits}

Of the 254 projects that currently registered at UNFCCC, a total of 171 projects (67\%) have no pending application for CER issuance (Table 8). The most affected type of project that has characterized this situation was the Biogas, wherein out of the 114 registered projects, only 26 have pending application with only 2 projects that have CER credits. Likewise, the Methane Avoidance with 26 registered projects has one project with pending application and with no CER credit earned so far.

Such result was contrary to the expectation that after the project has successfully obtained registration; the project shall immediately apply for CER issuance after a year or two to start generating revenues in line with the high investment and transaction costs during project implementation and operation. 
〈Table 8〉 Status of registered CDM projects of the ASEAN Countries

\begin{tabular}{c|c|c|c|r}
\hline Project Type & $\begin{array}{c}\text { Not Applied } \\
\text { for CER }\end{array}$ & $\begin{array}{c}\text { Applied } \\
\text { for CER }\end{array}$ & $\begin{array}{c}\text { Received } \\
\text { CER }\end{array}$ & Total \\
\hline Biogas & 86 & 26 & 2 & 114 \\
\hline Biomass & 18 & 18 & 6 & 42 \\
\hline Hydro Power & 17 & 4 & 1 & 22 \\
\hline Methane Avoidance & 25 & 1 & 0 & 26 \\
\hline Methane Recovery and Utilization & 13 & 6 & 1 & 20 \\
\hline Energy Efficiency and Other Energy Projects & 9 & 5 & 8 & 22 \\
\hline Other CDM Projects & 3 & 3 & 2 & 8 \\
\hline Total & 171 & 63 & 20 & 254 \\
\hline Percent to Total & 67.3 & 24.8 & 7.9 & 100.0 \\
\hline
\end{tabular}

To underscore this point, we investigated the involved transaction costs of CDM projects during project implementation and operation that includes project monitoring, verification and certification, broker's fee, adaptation levy and insurance fee. The hypothetical estimation of transaction cost at varying type of CDM projects was based on the expected annual emission reduction of 20,000 $\mathrm{tCO}_{2} \mathrm{e} / \mathrm{yr}, 60,000 \mathrm{tCO}_{2} \mathrm{e} / \mathrm{yr}$, and $120,000 \mathrm{tCO}_{2} \mathrm{e} / \mathrm{yr}$.

We assumed that the price of CER was US\$12/tCO 2 e $(9.50$ euro per CER) and all the projects have manually monitored the captured carbon emissions and as such, no metering devices were installed to automatically read the carbon emission reductions. The crediting period was assumed to be one whole year.

The results of our estimation show that the transaction cost of small CDM project with annual CER credit of 40,000tCO2e/yr was 
US\$3.57 per unit of CER while large project with annual CER credit of $200,000 \mathrm{tCO}_{2} \mathrm{e} / \mathrm{yr}$ had a transaction cost of US\$1.24 per unit of CER (Table 9). It can be deduced that the proponents of small CDM projects have to accumulate enough CER credits before they will apply for CER credit to significantly compensate the high transaction costs during project implementation and operation. As evident in Table 9, small CDM projects have to complete all the formalities of the project cycle during project operation and have to incur almost the same monitoring and verification costs as the large CDM projects.

$\langle$ Table 9〉 Estimated transaction cost of different scale of projects, in US\$

\begin{tabular}{|c|c|c|c|}
\hline & $\begin{array}{c}\text { Project A } \\
\text { (With 40,000 } \\
\mathrm{tCO}_{2} \mathrm{e} / \mathrm{yr} \text { CER } \\
\end{array}$ & $\begin{array}{c}\text { Project B } \\
\text { (With 100,000 } \\
\text { tCO }_{2} \mathrm{e} / \mathrm{yr} \text { CER } \\
\end{array}$ & $\begin{array}{c}\text { Project C } \\
\text { (With 200,000 } \\
\text { tCO }_{2} \mathrm{e} / \mathrm{yr} \text { CER } \\
\end{array}$ \\
\hline I. Revenue of CER & 312,000 & 780,000 & $1,560,000$ \\
\hline 1. Volume & 40,000 & 100,000 & 200,000 \\
\hline 2. Price per $\mathrm{tCO}_{2} \mathrm{e}$ & 12 & 12 & 12 \\
\hline 3. Performance Rate ${ }^{a /}$ & $65 \%$ & $65 \%$ & $65 \%$ \\
\hline II. Transaction Cost & 142,947 & 188,290 & 247,473 \\
\hline 1. Periodic Monitoring ${ }^{b /}$ & 78,000 & 78,000 & 78,000 \\
\hline 2. Verification and Certification ${ }^{c}$ & 20,000 & 22,000 & 25,000 \\
\hline 3. Sale of CER ${ }^{d /}$ & 32,105 & 56,184 & 80,263 \\
\hline 4. Adaptation levy ${ }^{\mathrm{e} /}$ & 6,421 & 16,053 & 32,105 \\
\hline 5. Risk Mitigation ${ }^{\mathrm{f} /}$ & 6,421 & 16,053 & 32,105 \\
\hline Cost per CER & 3.57 & 1.88 & 1.24 \\
\hline
\end{tabular}

a/ Average actual performance rate of Biogas with CER issuance which is defined as the rate of actual CER issued over estimated CER credit as written in the PDD.

b/ Cost that arise from the implementation of the monitoring plan, the periodic 
monitoring activities and the periodic submission of the monitoring report. Figures shown in the table are based on the assumption made by the IT Power Carbon Group and the Energy Research Center of the Netherland (ECN) for projects without an installed metering device that monitors the carbon emission.

c/ Cost that the project developer has to pay to the verifier. Figures shown in the table are based on World Bank's actual payment of such.

d/ Broker's fee for facilitating the CER trade. Figures shown in the table are based on the assumption made by the Ecosecurities broker's fee of 5-10\% of CER value. Here we applied 10\%, 7\% and 5\% of CER Revenue for the project A, B and C respectively. A higher value for small project with less CER has been assigned.

e/ $2 \%$ of CDM proceeds for use as an adaptation fund, a fund established by UNFCCC to help vulnerable countries adapt to the effects of climate change.

f/ This cost has been included by Ecosecurities regarding the payment of 1-3\% of CER value yearly, a mitigation fee against loss of incremental value as a consequence of project risk. This is a potential fee a developer may wish to incur so as to ensure against non-delivery of contracted CERs which may take in the form of a specific insurance. Here we applied $2 \%$ of CER Revenue for the each project type equally.

The above findings fully described what happened to the small projects of the ASEAN countries wherein out of the total 181 small projects, 38 projects $(21.0 \%)$ of which applied for CER issuance and only 7 projects $(4.0 \%)$ received CER.

More specifically, Table 10 shows that 40 CDM projects or 93\% of the total 43 Biogas projects with projected annual CER of below 20,000 $\mathrm{tCO}_{2} \mathrm{e} / \mathrm{yr}$ have no application yet for CER issuance. 
$\langle$ Table 10〉 Status of biogas project after registration

\begin{tabular}{c|c|c|c|c}
\hline & $\begin{array}{c}\text { Not applied } \\
\text { for CER }\end{array}$ & $\begin{array}{c}\text { Applied } \\
\text { for CER }\end{array}$ & $\begin{array}{c}\text { Received } \\
\text { CER }\end{array}$ & Total \\
\hline \begin{tabular}{c} 
Projected annual CER below 20,000 tCOe/yr \\
\hline $\begin{array}{c}\text { Projected annual CER between 20,000 and } \\
\text { 40,000 tCOe/yr }\end{array}$
\end{tabular} & 40 & 3 & - & 43 \\
\hline $\begin{array}{c}\text { Projected annual CER between 40,000 and } \\
\text { 60,000 tCOe/yr }\end{array}$ & 19 & 3 & - & 34 \\
\hline $\begin{array}{c}\text { Projected annual CER above 60,000 tCOe/yr } \\
\text { Total }\end{array}$ & 25 & 11 & 2 & 15 \\
\hline
\end{tabular}

In contrast, the two biogas projects that started receiving their CER credits were those projects with annual CER of more than $60,000 \mathrm{tCO}_{2} \mathrm{e} / \mathrm{yr}$. As evident, there was an inverse relationship of projects that applied for CER issuance with respect to its projected annual CER credit, that is, the lower the estimated credit of certain CDM registered projects, the higher the number of projects that do not apply for CER issuance; whereas, the higher the estimated credit, the higher the number of projects that apply for CER issuance.

\subsection{Characteristics of Projects with CER Credits}

What are the characteristics then of projects that have CER credits? To answer this issue, we used Probit Regression Analysis to determine the different variables that influenced the issuance of CER credits, the results of estimation are 
shown in Table 11.

\subsubsection{Project Scale}

The results of the Probit regression analysis show that the coefficient of project scale variable concerning large CDM project is positive and significant. The results suggest that large CDM projects could likely get CER credit than small projects. Given the high transaction cost per unit of CER for small projects as discussed in the previous section, the project proponent have to accumulate sufficient CER credits before they could start the processing of requirements for CER issuance.

The importance of small-scale projects in terms of sustainable development and emission reduction has been recognized by $\mathrm{CDM}-\mathrm{EB}$. As such, to assist these projects in overcoming the high transaction cost, the simplified modalities and procedures for small projects were later introduced. The result of our probit regression analysis, however, suggests that despite the simplified modalities and procedures given for small projects, the impact of such could hardly be felt during the period of study.

\subsubsection{Project Methodology}

In our regression analysis, we used the methodology concerning thermal energy production with or without electricity (AMS.I.C) as one of the independent variables. 
$\left\langle\right.$ Table 11〉 Probit analysis of projects with CER issuance ${ }^{\text {a/ }}$

\begin{tabular}{|c|c|c|c|c|}
\hline Name of Variables & $\begin{array}{l}\text { Estimated } \\
\text { Coefficient }\end{array}$ & $\begin{array}{l}\text { Standard } \\
\text { Error }\end{array}$ & T-Ratio & $\begin{array}{c}\text { Explanatory Notes } \\
\text { of Variables b) }\end{array}$ \\
\hline \multicolumn{5}{|l|}{ General } \\
\hline CDM Project Scale & 2.312 & 1.155 & $2.001^{*}$ & Large $=1$ \\
\hline CDM Project Methodology & 3.936 & 1.465 & $2.686^{* *}$ & AMS.I.C. $=1$ \\
\hline Age of the Project ${ }^{c}$ & 1.885 & 0.505 & $3.734^{* *}$ & \\
\hline \multicolumn{5}{|l|}{ CDM Sector } \\
\hline Biogas & -1.807 & 0.824 & $-2.194^{*}$ & Biogas $=1$ \\
\hline Methane Recovery & -0.568 & 0.825 & -0.689 & Methane Recovery=1 \\
\hline Energy Efficiency & 0.386 & 2.901 & 0.133 & Energy Efficiency=1 \\
\hline Wind Power & -0.506 & 1.557 & -0.325 & Wind Power=1 \\
\hline \multicolumn{5}{|l|}{ Host Country } \\
\hline Malaysia & -1.698 & 2.802 & -0.606 & Malaysia $=1$ \\
\hline Indonesia & 0.197 & 2.830 & 0.070 & Indonesia $=1$ \\
\hline Philippines & 0.586 & 2.875 & 0.204 & Philippines $=1$ \\
\hline Thailand & 1.291 & 2.955 & 0.437 & Thailand $=1$ \\
\hline Vietnam & 1.668 & 3.054 & 0.546 & Vietnam $=1$ \\
\hline \multicolumn{5}{|l|}{ Partner Country } \\
\hline Japan & 0.225 & 0.739 & 0.304 & Japan=1 \\
\hline U.K & 0.412 & 1.114 & 0.370 & $\mathrm{U} . \mathrm{K}=1$ \\
\hline Germany & 1.696 & 1.477 & 1.149 & Germany=1 \\
\hline Denmark & 1.848 & 1.216 & 1.520 & Denmark=1 \\
\hline Switzerland & 1.223 & 1.191 & 1.027 & Switzerland=1 \\
\hline \multicolumn{5}{|l|}{$\mathrm{DOE}$} \\
\hline $\mathrm{DNV}^{\mathrm{d} /}$ & -0.964 & 0.882 & -1.093 & $\mathrm{DNV}=1$ \\
\hline $\mathrm{SUD}^{\mathrm{e} /}$ & 0.208 & 1.181 & 0.176 & $\mathrm{SUD}=1$ \\
\hline Constant & -8.069 & 2.748 & $-2.153^{*}$ & \\
\hline \multicolumn{2}{|l|}{ ESTRELLA R-SQUARE } & 0.526 & & \\
\hline \multicolumn{2}{|l|}{ MADDALA R-SQUARE } & 0.336 & & \\
\hline
\end{tabular}




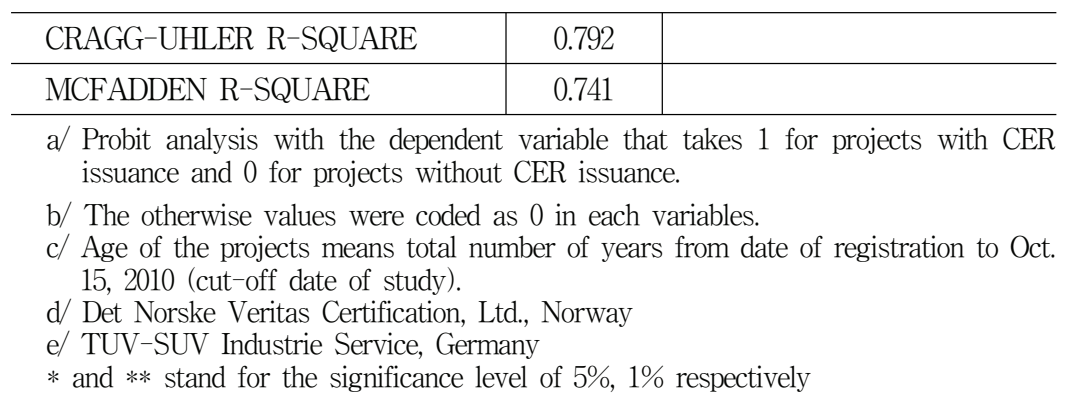

Projects under this methodology, as defined by UNFCCC, are those renewable energy technologies that supplied users with thermal energy to displace the use of fossil fuel including the solar thermal water heaters and dryers, solar cookers, energy derived from renewable biomass and other technologies that provide thermal energy to displace fossil fuel. Biomass-based cogeneration systems consisting of steam generator and steam turbine are included in this category.

The results of our regression analysis show that the coefficient of project methodology variable concerning AMS.I.C is positive and highly significant. The result suggests the likelihood of projects getting CER credit that uses this methodology. Of the 254 study projects, there were 28 registered projects that used this methodology alone or combined with other methodologies. These include 17 Biomass projects, 9 Biogas projects and one each from projects classified as Energy Efficiency and Other Renewable Energy.

It is noteworthy to mention that the development of methodology is critical in expanding the output of CDM, since 
each new methodology has the potential to unleash a new path of different type of project/activity in order to access the carbon finance.

\subsubsection{Time of Project Registration}

This variable, as measured by the total number of years the project has been registered at UNFCCC, is shown to be an important factor that characterizes the presence of CER credits of the project. As expected, the results of our regression analysis show that the estimated coefficient of this variable is positive and significant. The result suggests that the longer the projects have been registered at UNFCCC, the higher the possibility that these projects have earned CER credits. The result is likewise consistent with our previous findings concerning the time elements of the project, wherein there exists delay in project implementation and operation that hinders the issuance of CER credit, and the project participants were accumulating sufficient amount of CER credits before they start preparing the necessary requirements for the application of CER credits, an strategy most likely adopted by the proponents of small CDM projects.

\subsubsection{Type of CDM Project}

Based on the data of UNFCCC, majority of the Biogas CDM projects in the world were hosted by Thailand, Malaysia, and the Philippines, and these registered projects were situated 
in commercial livestock farms. By installing a biogas unit, the animal manure that was previously deposited in an open lagoon under the baseline scenario was fermented in the biogas digester and the methane emission was avoided. Biogas has been used to replace fossil fuels for heating purposes or for processing heat and electricity by introducing a CHP unit.

The results of our estimation show that the coefficient of Biogas variable is negative and significant. The results of our analysis thus statistically confirmed our earlier findings that Biogas was likely at the disadvantage position of getting CER credit at the moment because majority of this kind of projects are basically small.

\subsubsection{Participating Host and Partner Countries}

The fairness and effectiveness of the CDM in reducing greenhouse gas emissions and promoting economic development is a matter of substantial concern for the international community. While the ASEAN members may see themselves as natural competitors for CDM investments, the result of our regression analysis regarding the variability of projects with CER issuance suggests that there was no distinct advantage of one country with the others. The result was consistent with the joint commitment of ASEAN members for cooperation in addressing environment issues that include close coordination and sharing of information, technical and legal expertise and regional capability building in the implementation and operation of CDM projects. 
Likewise, the result of regression analysis regarding the influence of partner developed countries in getting CER credit is not significant. The result indicates the absence of any advantage of one country over the other in terms of CER implementation and operation, and finally, the application and issuance of CER credit.

\subsubsection{Designated Operating Entity}

As discussed in the previous section, the designated operating entities(DOE), such as the Det Norske Veritas Certification Ltd. (DNV) and TUV-SUV Industrie Service (TUV-SUV), and others, play a vital role in the validation and verification of CER credit of CDM projects. The results of our regression analysis, as expected, indicate that there is no influence at all of DOE in the issuance of CER credit. This result was consistent with the $\mathrm{CDM}$ framework regarding the role of DOE in the verification and application of CER credit for being a fair and independent body.

\section{Conclusion and Policy Implication}

Using a database of 254 projects registered at the UNFCCC as of October 15, 2010, this research has examined the performance of CDM registered projects of ASEAN countries since the start of Kyoto Protocol in 2004 and as it approaches 
its end in 2012.

Undeniably, the CDM has fulfilled its promise of providing additional direct investments and transfer of technologies to ASEAN developing countries in line with the large number of projects registered so far. The Kyoto Protocol has indeed successfully created a mechanism of encouraging ASEAN countries to participate in reducing carbon emissions and become part of the concerted efforts of addressing the problem on climate change.

However, our study revealed that out of the 254 projects that successfully registered at UNFCCC, there were only 20 projects that received CER credit or $8 \%$ of the total registered projects in the world. The actual CER credits earned have reached 6.5 million $\mathrm{tCO}_{2} \mathrm{e}$ during the period but this only represents $15 \%$ of the potential CER credits that could be earned by the ASEAN countries based on the delivery schedule of registered projects as stipulated in their individual Project Design Document. One large project in Vietnam accounts for $69 \%$ of the total CER issued in the ASEAN Region and as such, without it, the participation rate of the ASEAN Region in the CER credit earned could be very low. Given the low delivery rate of $15 \%$, the result of our research thus suggests that the CDM projects in the ASEAN countries failed to deliver on time the expected volume of CER credit for the developed countries that bind to reduce their CER emission by 2012, the closing of Kyoto Protocol.

The major factors that influenced the low performance of 
CDM projects in the ASEAN Region were as follows: (1) the long duration of completing all the requirements of the project before it will start receiving CER credits, the average estimated duration is 4.9 years; (2) the low performance of CER projects in terms of actual CER credit issuance over the projected CER credit to be earned; and, (3) most of the CDM projects did not apply for CER credit right after registration which was partly due to the high transaction costs during project operation particularly for small scale projects. Registered CDM projects of ASEAN countries were composed mostly of small scale projects comprising $71 \%$ of the total.

While there were several attempts by the CDM-EB to simplify procedures and modalities for small scale projects in addition to the bundling of qualified small projects to further reduce the transaction cost during the preparation of the Project Design Document, validation, registration, monitoring, verification and issuance of projects, the impact of such can hardly be felt during the coverage of the study period.

Undeniably, majority of the countries in the ASEAN Region became active partners of developed countries in establishing and registering CDM projects but along the project cycle, some serious vulnerability of the current system along the project cycle exists. Considering that some of the members of the ASEAN countries have committed to reduce their own carbon emission under the Copenhagen Accord, these countries should be given more assistance for them to successfully manage, implement, 
and operate their own CDM-like projects in the future.

Capability building shall be aggressively pursued in order to properly empower the ASEAN countries to manage, implement and operate CDM-like projects particularly during the post-Kyoto protocol. 


\section{- References}

Capoor, K., \& Ambrosi, P. (2008). State and Trends of the Carbon Market 2006. Washington DC, World Bank.

IGES. (2010). Towards CDM reform. Report of the IGES CDM Capacity Building Kyoto General Meeting. Kanagawa, Japan. Institute for Global Environmental Strategies(IGES).

Lloyd, B., \& Subbarao S. (2008). Development Challenges Under the Clean Development Mechanism(CDM)-Can Renewable Energy Initiatives be Put in Place Before Peak Oil. Energy Policy, 37, 237-245.

Lutken, S. E., \& Michaelowa, A. (2008). Corporate Strategies and the Clean Development Mechanism. Developing Country Financing for Developed Country Commitments?. Edward Elgar publishing, Cheltenham, UK.

Michaelowa, A. (2007b). Unilateral CDM-Can Developing Countries Finance Generation Of Greenhouse Gas Emission Credits On Their Own?. International Environmental Agreements, 7(18), 17-34.

Michaelowa, A., \& Stonzik M. (2002). Transaction Costs of the Kyoto Mechanism. Discussion Paper. Hamburgisches Welt-Wrtschafts-Archiv(HWWA).

Olmstead, S., \& Stavins, R. (2010). Three Key Elements of Post-2012 International Climate Policy Architect. Discussion Paper. Harvard Project on International Climate Agreement. Washington DC.

Scheba, A. (2010). The Clean Development Mechanism: Sustainable Development Through Carbon Trading? An Analysis with a South African Case Study. VDM Verlag Dr. Muller Publishing.

UNFCCC. Draft Decision CP-15. Outcome of the Work of AdHoc Working Group on Long Term Cooperative Action Under the Convention. http://unfccc.int/resource/docs/ 2009/cop15/.../107.pd

UNFCCC. Guidelines for Completing the Forms for Submission of Bundled SmallScale CDM Projects Activities(F-CDM-SSC-Bundle). Online. Internet download. http://cdm.unfccc.int/EB/021/ Feb21repan21.pdf 
World Bank. (2010a). Clean Development Mechanism In China: Five Years Of Experience (2004-09). Washington DC, World Bank.

World Bank. (2010b). 10 Years of Experience in Carbon Finance: Insights From Working With the Kyoto Mechanisms. Washington DC, World Bank.

http://www.iges.or.jp/en/cdm/report.html

http://cdm.unfccc.int/methodologies/ index.html

http://cdm.unfccc.int/Issuance/ index.html

http://cdm.unfccc.int/Projects/projsearch.html 